CORRECTION

\title{
Correction: Multi-locus characterization and phylogenetic inference of Leishmania spp. in snakes from Northwest China
}

\section{The PLOS ONE Staff}

The Author Contributions for Minli Chen are incorrect. The correct contributions for Minli Chen are: Investigation, Software. The publisher apologizes for the error.

\section{Reference}

1. Chen H, Li J, Zhang J, Guo X, Liu J, He J, et al. (2019) Multi-locus characterization and phylogenetic inference of Leishmania spp. in snakes from Northwest China. PLoS ONE 14(4): e0210681. https://doi. org/10.1371/journal.pone.0210681 PMID: 31022192

\section{G open Access}

Citation: The PLOS ONEStaff (2019) Correction: Multi-locus characterization and phylogenetic inference of Leishmania spp. in snakes from Northwest China. PLoS ONE 14(8): e0221307. https://doi.org/10.1371/journal.pone.0221307

Published: August 13, 2019

Copyright: @ 2019 The PLOS ONE Staff. This is an open access article distributed under the terms of the Creative Commons Attribution License, which permits unrestricted use, distribution, and reproduction in any medium, provided the original author and source are credited. 